\title{
PERMOHONAN PENETAPAN PERWALIAN ANAK OLEH IBU KANDUNG (Studi Penetapan Nomor: 31/Pdt.P/2020/PN Srh)
}

\author{
${ }^{1}$ Ega Wulandari, ${ }^{2}$ Manfarisyah, ${ }^{2}$ Jumadiah \\ ${ }^{1}$ Fakultas Hukum, Universitas Malikussaleh \\ ${ }^{2}$ Dosen Fakultas Hukum, Universitas Malikussaleh \\ Co. Author : jumadiah@unimal.ac.id
}

\begin{abstract}
This study aims to find out the reason for the birth mother to apply for a child guardianship application, the basis for the judge's consideration in granting a child guardianship application, and the legal consequences after the guardianship determination. The method in this study is to use research with an empirical juridical approach, with qualitative legal research types, and the legal sources used are through field research. The results in this study are that the reason for the biological mother to apply is to fulfill the requirements to borrow money from the bank by guaranteeing a Certificate of Ownership and the money is used for the purposes of her child's school fees. The basis for the judge's consideration in granting this application is based on Article 47 of Law Number 1 of 1974 concerning Marriage which states that parents can represent their children as long as their powers are never revoked. And as a result of this determination, whether or not there is a decision from the court, the biological mother can still represent her child in legal action.
\end{abstract}

Keywords: Application, Guardianship, Children 


\section{PENDAHULUAN}

Berdasarkan Pasal 1 ayat (2) Undang-Undang Nomor 4 Tahun 1979 tentang Kesejahteraan Anak : "Anak adalah seseorang yang belum mencapai umur 21 (dua puluh satu) tahun dan belum pernah kawin”. Dengan demikian anak seusia ini benar-benar membutuhkan kesejahteraan dan perlindungan dalam perkembangan hidupnya. Orang yang pertama kali berhak untuk melakukan perlindungan terhadap kepentingan diri seorang anak adalah orang tua anak tersebut. Hal ini sesuai dengan Pasal 299 KUH Perdata, yang menyatakan tentang asas-asas kekuasaan orang tua. Pasal ini menerangkan bahwa : Pasal ini menerangkan bahwa : "Selama perkawinan orang tuanya, setiap anak sampai dewasa tetap berada dalam kekuasaan kedua orang tuanya, sejauh kedua orang tua tersebut tidak dilepaskan atau dipecat dari kekuasaan itu". Ada sesuatu yang membuat kewenangan orang tua dicabut dalam perwalian, sehingga mereka tidak dapat menggunakan kekuasaan terhadap anak, sehingga kekuasaan mereka harus digantikan oleh wali. Jadi dapat disimpulkan, wali adalah seseorang yang mengambil alih wewenang orang tua yang kehilangan kendali atas anaknya karena orang tua tersebut meninggal atau bercerai.

Secara hukum orang tua dapat mewakili anaknya di dalam maupun di luar pengadilan, hal seperti ini di atur dalam Pasal 47 Undang-Undang Nomor 1 Tahun 1974 tentang Perkawinan. Namun, pada kenyatannya penulis menemukan satu perkara yang keluar dari ketentuan-ketentuan di atas, dimana seorang ibu kandung memohon penetapan perwalian kepada Pengadilan Negeri Sei Rampah atas anak kandungnya, yang permohonan tersebut tercatat dengan Nomor register 31/Pdt.P/2020/PN Srh.

Penetapan tersebut berisi tentang pengajuan permohonan perwalian yang dilakukan oleh ibu atas anak kandungnya yang mana pemohon telah menikah dengan seorang laki-laki yang bernama Sri Rahmad Hasibuan pada tanggal 13 Maret 1986 dan dikaruniai 4 (empat) orang anak. Selanjutnya pada tanggal 23 Juni 2014, suami pemohon meninggal dunia karena sakit sesuai dengan surat kematian Nomor: 18.40.1/474.3/343/2020 tertanggal 21 Februari 2020 yang dikeluarkan oleh Kepala Desa Sei Rampah. Suami pemohon selain meninggalkan pemohon juga meninggalkan harta warisan berupa tanah dan bangunan berdasarkan Sertifikat Hak Milik No. 43 seluas 1057 M $^{2}$ (Seribu lima puluh tujuh meter persegi) atas nama Ida Sumarni, yang terletak di Desa Simpang Empat Kecamatan Sei Rampah Kabupaten Serdang Bedagai Provinsi Sumatera Utara. Pemohon mengajukan permohonan untuk dapat mewakili anaknya yang belum dewasa dalam bertindak secara hukum. Perbuatan hukum yang dimaksud adalah, pemohon bermaksud untuk meminjam uang dan menjaminkan SHM (Sertifikat Hak Milik) tersebut kepada pihak bank yang mana uangnya akan digunakan pemohon untuk keperluan biaya pendidikan anak pemohon yang masih sekolah/kuliah. Bahwa pemohon memiliki anak yang belum dewasa bernama Aldi Azhari Hasibuan, dan untuk kepentingan tersebut adalah wajar apabila Pemohon selaku ibu kandung menjadi Wali dari Aldi Azhari Hasibuan. Bahwa untuk bertindak atas kepentingan pemohon, pemohon terlebih dahulu harus mendapatkan Penetapan dari Pengadilan Negeri. Dalam hal ini Hakim mengabulkan permohonan pemohon. ${ }^{1}$

\footnotetext{
${ }^{1}$ Salinan penetapan Nomor: 31/Pdt.P/2020/PN Srh.
} 


\section{METODE PENELITIAN}

Dala penelitian ini ada dua permasalahan yang akan dijawab, yaitu Apakah alasan ibu kandung mengajukan permohonan penetapan perwalian dan Apakah dasar pertimbangan hakim dalam mengabulkan permohonan penetapan perwalian anak oleh ibu kandung berdasarkan penetapan Nomor: 31/Pdt.P/2020/PN Srh . Penelitian ini menggunakan jenis penelitian Kualitatif. ${ }^{2}$ Pendekatan penelitian yang digunakan yaitu yuridis empiris dengan cara melakukan penelitian dengan mengumpulkan data primer secara langsung dari objek penelitian melalui tahapan wawancara dengan informan, responden dan narasumber yang berhubungan dengan objek penelitian. $^{3}$

\section{PEMBAHASAN}

1. Permohonan

M. Yahya Harahap menjelaskan bahwa permohonan atau gugatan voluntair adalah permasalahan perdata yang diajukan dalam bentuk permohonan yang di tanda tangani pemohon atau kuasanya yang ditujukan kepada Ketua Pengadilan Negeri. ${ }^{4}$ Landasan hukum permohonan atau gugatan voluntair merujuk pada ketentuan Pasal 2 dan penjelasan Pasal 2 ayat (1) Undang-Undang Nomor 48 Tahun 2009 tentang Ketentuan-Ketentuan Pokok Kekuasaan Kehakiman.

Proses pemeriksaan permohonan di pengadilan dilakukan secara ex-parte yang bersifat sederhana yaitu hanya mendengarkan keterangan pemohon, memeriksa bukti surat atau saksi yang diajukan pemohon dan tidak ada tahap replik-duplik dan kesimpulan. Setelah permohonan diperiksa, maka pengadilan akan mengeluarkan penetapan atau ketetapan (beschikking/decree).

\section{Penetapan dan Putusan Hakim}

Penetapan adalah keputusan pengadilan atas perkara permohonan (voluntair), misalnya penetapan dalam perkara dispensasi nikah, izin nikah, wali adat, poligami, perwalian, itsbat nikah, dan sebagainya. Penetapan merupakan jurisdiction valuntaria (bukan peradilan yang sesungguhnya) karena pada penetapan hanya ada pemohon, tetapi tidak ada lawan hukum. Dalam penetapan, hakim tidak menggunakan kata "mengadili", tetapi "menetapkan". 5

Putusan hakim adalah hukum atau undang-undang yang mengikat antar para pihak yang bersangkutan. Putusan tidak boleh mengabulkan melebihi tuntutan yang dikemukakan dalam gugatan, larangan ini disebut Ultra Petitum Partium. Hasil penetapan ataupun putusan dibacakan dalam sidang terbuka untuk umum. Hal ini merupakan bagian dari asas fair trial dengan tujuan untuk menjamin proses peradilan terhindar dari perbuatan tercela dari pejabat pengadilan. Hal ini ditegaskan dalam Pasal 13 Undang-Undang Nomor 4 Tahun 2009 tentang Kekuasaan Kehakiman. Apabila dilanggar, maka ini mengakibatkan putusan tidak sah dan tidak mempunyai kekuatan hukum.

${ }^{2}$ Fakultas Hukum Universitas Malikussaleh, Buku Panduan Tugas Akhir, Lhokseumawe, 2015, hlm.

8.

${ }^{3}$ Bambang Sugono, Metode Penelitian Hukum, Ghalia Indonesia, Jakarta, 1990, hlm.10.

${ }^{4}$ M. Yahya Harahap, Hukum Acara Perdata Tentang Gugatan, Persidangan, Penyitaan, Pembuktian, dan Putusan Pengadilan, Sinar Grafika, Jakarta, 2005, hlm. 29.

${ }^{5}$ Moh. Fauzan Januri, Analisis Yurisprudensi, Pustaka Setia, Bandung, 2018, hlm. 82. 
3. Kekuasaan Orang Tua

a) Kekuasaan Orang Tua Terhadap Diri Anak

Kekuasaan orang tua hanya ada selama orang tua itu memenuhi kewajiban-kewajibannya terhadap anak-anaknya dengan baik dan selama tidak di cabut atau di bebaskan. Kewajiban yang dibebankan kepada orang tua tersebut berupa wajib nafkah (kewajiban alimentasi) yaitu kewajiban untuk memelihara dan mendidik anak-anaknya yang belum cukup umur (Pasal 298 ayat (2) KUH Perdata). Berdasarkan hal tersebut, setiap anak di bawah umur, dan bagi mereka yang berusia kurang dari 21 (dua puluh satu) tahun dan tidak pernah melakukan perkawinan. Sehingga kepadanya belum dapat mengadakan persetujuan-persetujuam maka itu orang tualah yang wajib menyelenggarakan segala kebutuhannya.

\section{b) Kekuasaan Orang Tua Yang Dicabut Kekuasaannya}

Perwalian muncul berdasarkan kekuasaan orang tua yang sudah meninggal atau dicabutnya kekuasaan orang tua oleh pengadilan berdasarkan keputusan pengadilan. Pasal 47 ayat (1) Undang-Undang Nomor 1 Tahun 1974 tentang Perkawinan menyebutkan bahwa "Anak yang belum mencapai umur 18 (delapan belas) tahun atau belum pernah melangsungkan perkawinan ada di bawah kekuasaan orang tuanya selama mereka tidak dicabut dari kekuasaannya'. Pasal 47 ayat (2) Undang-Undang Nomor 1 Tahun 1974 tentang Perkawinan mengatur bahwa orangtua mewakili anak tersebut mengenai perbuatan hukum di dalam dan di luar pengadilan.

\section{Perwalian}

Perwalian (voogdij) menurut Undang-Undang Nomor 1 Tahun 1974 tentang Perkawinan adalah pengawasan atau pengurusan terhadap pribadi anak di bawah umur atau belum dewasa yang tidak di bawah kekuasaan orang tua serta pengurusan harta benda anak sebagaimana diatur dalam undang-undang. ${ }^{6}$

a. Syarat Wali

Menurut Pasal 33 Undang-Undang Nomor 35 Tahun 2014 tentang Perlindungan Anak, syarat wali adalah :

1) Seseorang atau badan hukum yang memenuhi persyaratan dapat ditunjuk sebagai wali dari anak yang bersangkutan.

2) Untuk menjadi Wali dari Anak dilakukan melalui penetapan pengadilan.

3) Wali yang ditunjuk harus memiliki kesamaan dengan agama yang dianut Anak.

4) Wali bertanggung jawab terhadap diri Anak dan wajib mengelola harta milik Anak yang bersangkutan untuk kepentingan terbaik bagi Anak.

5) Ketentuan lebih lanjut mengenai syarat dan tata cara penunjukan Wali sebagaimana dimaksud pada ayat (1) diatur dengan Peraturan Pemerintah.

b. Macam-macam Perwalian

Perwalian ditinjau dari segi pengangkatannya terdiri dari 3 (tiga) macam, yaitu: ${ }^{7}$

1. Perwalian oleh suami atau isteri yang hidup paling lama;

2. Perwalian yang ditunjuk oleh bapak atau ibu dengan surat wasiat atau akta tersendiri.

3. Perwalian yang diangkat oleh Hakim.

${ }^{6}$ Umar Said Sugiarto, Pengantar Hukum Indonesia, Cetakan Kedua, Sinar Grafika, Jakarta, Februari 2015, hlm. 140.

${ }^{7}$ Mustofa Hasan, Pengantar Hukum Keluarga, CV Pustaka Setia, Bandung, 2011, hlm. 278-279. 
i.Berakhirnya Perwalian

Berakhirnya perwalian dapat ditinjau dari dua segi, yaitu: ${ }^{8}$

1) Dalam hubungan dengan keadaan anak (absolut)

a) Si anak telah dewasa (meerderjaring)

b) Si anak meninggal dunia (minderjaring)

c) Kembalinya kekuasaan orang tuanya (ouderlijkkemach)

d) Pengesahan seorang anak luar kawin

2) Dalam hubungan dengan tugas wali (relatif)

a) Ada pemecatan atau pembebasan atas diri si wali

b) Ada alasan pembebasan atau pemecatan dari perwalian (Pasal 380 KUH Perdata).

\section{HASIL PENELITIAN DAN PEMBAHASAN}

A. Alasan Ibu Kandung mengajukan permohonan penetapan perwalian

Hasil wawancara, alasan pemohon mengajukan permohonan penetapan perwalian ke Pengadilan Negeri dikarenakan pihak bank meminta surat penetapan perwalian yang di keluarkan oleh pihak pengadilan untuk dijadikan syarat dalam menjaminkan Sertifikat Hak Milik atas nama Ida Sumarni untuk meminjam uang. Adapun alasan pihak bank meminta surat penetapan perwalian dari pengadilan untuk dijadikan bukti autentik agar menghindari terjadinya sengketa di kemudian hari, dikarenakan masih adanya anak pemohon yang belum dewasa yang bernama Aldi Azhari Hasibuan. ${ }^{9}$

Pemohon mengajukan pinjaman ke pihak bank dengan menjaminkan Sertifikat Hak Milik atas nama Ida Sumarni, pemohon sudah menjelaskan kepada pihak bank dimana pemohon memiliki anak yang belum cakap hukum yang bernama Aldi Azhari Hasibuan dan pemohon juga berhak mewakili anaknya yang bernama Aldi Azhari Hasibuan dalam menjaminkan Sertifikat Hak Milik kepada pihak bank. Berdasarkan hal tersebut, anak kandung pemohon yang lain tidak merasa keberatan apabila pemohon menjaminkan Sertifikat Hak Milik atas nama Ida Sumarni kepada pihak bank. Selama menjadi orang tua, pemohon tidak pernah di cabut kekuasaannya sehingga pemohon berhak untuk mewakili anaknya dalam menjaminkan Sertifikat Hak Milik tersebut kepada pihak bank. ${ }^{10}$

Apabila pemohon tidak pernah dicabut kekuasaannya maka pemohon berhak mewakili anaknya bertindak secara hukum. Hal tersebut dapat dilihat dalam Pasal 47 ayat (2) UndangUndang Nomor 1 Tahun 1974 tentang Perkawinan yang menyatakan orang tua mewakili anak tersebut mengenai segala perbuatan hukum di dalam dan di luar pengadilan. Dengan demikian pemohon dapat mewakili anaknya karena pemohon telah memenuhi kriteria sebagai wali untuk mewakili anaknya yang masih di bawah umur

B. Dasar pertimbangan hakim dalam mengabulkan permohonan penetapan perwalian anak oleh ibu kandung berdasarkan penetapan Nomor: 31/Pdt.P/2020/PN Srh.

Pertimbangan Hakim Pengadilan Negeri Sei Rampah dalam menetapkan perkara Nomor:31/Pdt.P/2020/PN Srh adalah sebagai berikut: ${ }^{11}$ Menimbang, bahwa berdasarkan bukti

${ }^{8}$ Ibid, hlm. 283.

${ }^{9}$ Ida Sumarni, Pemohon, Wawancara, tanggal 15 Februari, 2021.

${ }_{10}$ Ibid.

${ }^{11}$ Ekho Pratama, Hakim Pengadilan Negeri Sei Rampah, Wawancara, tanggal 17 Februari 2021. 
P-1 berupa fotokopi kartu tanda penduduk Pemohon dan bukti P-5 berupa fotokopi kartu keluarga serta dihubungkan dengan keterangan saksi-saksi yang saling bersesuaian, maka diperoleh fakta bahwa pemohon bertempat tinggal di Dusun VI Desa Sei Rampah, Kecamatan Sei Rampah, Kabupaten Serdang Bedagai, yang termasuk dalam wilayah hukum Pengadilan Negeri Sei Rampah.

Menimbang, bahwa pokok permohonan pemohon adalah mengenai permohonan izin pemohon sebagai ibu kandung dari anak yang belum cakap hukum yang bernama Aldi Azhari Hasibuan untuk menjaminkan harta warisan peninggalan suami pemohon berupa sebidang tanah dan bangunan seluas $1057 \mathrm{~m}^{2}$ yang terletak di Desa Simpang Empat, Kecamatan Sei Rampah, Kabupaten Serdang Bedagai dahulu Kabupaten Deli Serdang, Provinsi Sumatera Utara, sebagaimana tercatat dalam Sertifikat Hak Milik Nomor: 43 atas nama Ida Sumarni, dengan tujuan untuk keperluan biaya pendidikan anak pemohon yang masih sekolah dan akan memasuki jenjang kuliah;

Menimbang, bahwa berdasarkan bukti P-5 dan P-7 dihubungkan dengan keterangan saksisaksi, diketahui bahwa Aldi Azhari Hasibuan adalah anak kandung Pemohon dari pernikahannya dengan Sri Rahmad Hasibuan, dimana Aldi Azhari Hasibuan adalah anak keempat laki-laki yang lahir di Sei Rampah tanggal 26 April 2005, dengan demikian saat permohonan ini didaftarkan, umur Aldi Azhari Hasibuan adalah 15 (lima belas) tahun;

Menimbang, berdasarkan Pasal 47 ayat (1) Undang-Undang Nomor 1 Tahun 1974 tentang Perkawinan, anak yang belum mencapai umur 18 (delapan belas) tahun atau belum pernah melangsungkan perkawinan ada di bawah kekuasaan orang tuanya selama mereka tidak dicabut kekuasaannya, dan dalam ayat (2) diatur bahwa orang tua mewakili anak tersebut mengenai segala perbuatan hukum di dalam dan di luar Pengadilan;

Menimbang, bahwa meskipun demikian, dalam Pasal 345 Kitab Undang-Undang Hukum Perdata di atur bahwa "Apabila salah satu dari kedua orang tua meninggal dunia, maka perwalian terhadap anak-anak kawin yang belum dewasa, demi hukum di pangku oleh orang tua yang hidup terlama sekedar ini tidak telah di bebaskan atau di pecat kekuasaan orang tuanya."

Menimbang, bahwa setelah mencermati fakta bahwa pemohon adalah satu-satunya orang tua Aldi Azhari Hasibuan yang tersisa setelah ayahnya yang sudah tiada, maka demi hukum berdasarkan Pasal 345 Kitab Undang-Undang Hukum Perdata, pemohon adalah orang tua sekaligus wali dari anak yang bernama Aldi Azhari Hasibuan, dimana kekuasaan ada pada pemohon selaku orang tua Aldi Azhari Hasibuan adalah perwalian menurut undang-undang (wettwlijke voogdij).

Menimbang, bahwa oleh karena permohonan ini untuk kepentingan pemohon, dan sebagaimana pertimbangan diatas telah di nyatakan di kabulkan, maka pemohon di bebani untuk membayar biaya permohonan ini yang besarnya akan di tentukan dalam amar penetapan ini.

Pengadilan Negeri sudah membahas pokok perkara berdasarkan pertimbanganpertimbangan. Oleh karena permohonan pemohon cukup beralasan maka patut dikabulkan karena pemohon dapat membuktikan dalil-dalil permohonan. ${ }^{12}$

Hakim mengabulkan penetapan ini dengan pertimbangan mengedepankan kemanfaatan, memberikan kepastian hukum dan keadilan bagi pemohon, pertimbangan Hakim dalam

${ }^{12}$ Ekho Pratama, Hakim Pengadilan Negeri Sei Rampah, Wawancara, tanggal 17 Februari 2021. 
mengabulkan permohonan pada Penetapan Nomor: 31/Pdt.P/2020/PN Srh. Pemohon membutuhkan biaya untuk kepentingan pendidikan anaknya, dan untuk tidak terjadi perselisihan, sengketa ataupun tuntutan dikemudian hari, penetapan pengadilan wajib dilaksanakan. ${ }^{13}$

Dikabulkannya Penetapan Nomor: 31/Pdt.P/2020/PN Srh, yang memberikan kemudahan untuk menjaminkan Sertifikat Hak Milik kepada pihak bank bagi pemohon dalam mewakili anaknya, karena penetapan pengadilan sangat dibutuhkan pemohon dalam mewakili anak di bawah umur.

Pemohon selaku ibu kandung sangat tepat, mengingat anak tersebut belum dikategorikan dewasa, sedangkan di sisi lain pemohon selama dalam pemeriksaan tidak terindikasi sebagai ibu yang melanggar hukum seperti pemabuk, boros, penjudi atau melakukan hal-hal yang dilarang agama dan hukum, dengan demikian Hakim berpendapat permohonan pemohon untuk menjadi wali bagi anaknya yang belum cakap hukum. ${ }^{14}$

Hakim memberikan izin kepada pemohon untuk menjadi wali bagi anaknya, dimana Hakim mengabulkan semua permohonan perwalian oleh pemohon yang bersangkutan. Penetapan ini juga mengizinkan ibu anak di bawah umur untuk mengelola ataupun mempergunakan harta warisan milik kedua anak tersebut yang berasal dari harta peninggalan ibunya, yang dimaksudkan untuk dipergunakan bagi kepentingan anaknya sampai dengan anak tersebut cukup umur, mulai dari segi kebutuhan sehari-hari, pendidikan, sandang, pangan, dan lain sebagainya.

C. Akibat setelah adanya penetapan perwalian

Akibat dari dikabulkannya permohonan oleh pemohon maka pemohon dapat bertindak mewakili anaknya dalam meminjam uang kepada pihak Bank dan menjaminkan Sertifikat Hak Milik atas nama pemohon kepada pihak Bank, dimana uangnya digunakan untuk keperluan biaya sekolah anak pemohon yang belum cakap hukum. Karena dilakukannya perwalian memiliki fungsi terhadap diri seorang anak untuk menjaga kesejahteraan anak, mengawasi halhal yang berhubungan dengan dirinya dan segala macam yang belum dapat diperolehnya. Seperti pemeliharaan, perawatan, dan pendidikan seorang anak yang masih di bawah umur. ${ }^{15}$

\section{KESIMPULAN}

Alasan ibu kandung dalam mengajukan permohonan penetapan perwalian ke Pengadilan untuk memenuhi syarat dalam meminjam uang kepada pihak bank dengan menjaminkan Sertifikat Hak Milik dan uang tersebut digunakan untuk keperluan biaya pendidikan anaknya yang masih dibawah umur. Dasar Pertimbangan Hakim Pengadilan Negeri Sei Rampah mengabulkan permohonan penetapan ibu kandung sebagai wali terhadap anak di bawah umur dalam Penetapan Nomor: 31/Pdt.P/2020/PN Srh adalah bahwa dalam persidangan diperoleh fakta bahwa Pemohon tidak pernah di cabut kekuasaannya sebagai orang tua dari anak bernama Aldi Azhari Hasibuan, dengan demikian Pemohon sesuai dengan Pasal 47 ayat (2) Undang-Undang Nomor 1 Tahun 1974 tentang Perkawinan berhak untuk mewakili anak bernama Aldi Azhari Hasibuan tersebut untuk melakukan perbuatan hukum di dalam dan di luar pengadilan.

13 Ekho Pratama, Hakim Pengadilan Negeri Sei Rampah, Wawancara, tanggal 17 Februari 2021.

14 Ekho Pratama, Hakim Pengadilan Negeri Sei Rampah, Wawancara, tanggal 17 Februari 2021.

15 Ida Sumarni, Pemohon, Wawancara, tanggal 04 Maret 2021. 
Akibat setelah adanya penetapan dari Pengadilan Negeri yaitu ada atau tidaknya penetapan dari Pengadilan Negeri maka ibu kandung selaku pemohon berhak mewakili anaknya bertindak secara hukum dan dapat mewakili anaknya dalam menjaminkan Sertifikat Hak Milik kepada bank untuk meminjam uang.

\section{Daftar Pustaka}

Amiruddin dan Zainal Asikin, 2020, Pengantar Metode Penelitian Hukum, cetakan keenam, PT. Rajagrafindo Persada, Jakarta.

Bambang Sugono, 1990, Metode Penelitian Hukum, Ghalia Indonesia, Jakarta.

Fakultas Hukum Universitas Malikussaleh, 2015, Buku Panduan Tugas Akhir, Lhokseumawe.

M. Yahya Harahap, 2005, Hukum Acara Perdata Tentang Gugatan, Persidangan, Penyitaan, Pembuktian, dan Putusan Pengadilan,_Sinar Grafika, Jakarta.

Moh. Fauzan Januri, 2018, Analisis Yurisprudensi, Pustaka Setia, Bandung.

Mustofa Hasan, 2011, Pengantar Hukum Keluarga, CV Pustaka Setia, Bandung.

Umar Said Sugiarto, 2015, Pengantar Hukum Indonesia, Cetakan Kedua, Sinar Grafika, Jakarta. 